\title{
Computer modelling of fire resistant solutions for structures in high-rise buildings with using of new fire-retardant materials
}

\author{
Marina Gravit $^{1}$, Eliza Gumerova ${ }^{1 *}$, and Vladimir Lulikov ${ }^{1}$ \\ ${ }^{1}$ Peter the Great St. Petersburg Polytechnic University, 195251, Politechnicheskaya st., 29, Russian \\ Federation
}

\begin{abstract}
The article describes possibilities of computer modeling of fire resistance for structures in high-rise buildings, which include new fireresistant plaster compositions. As an example of program complex, "Sofistik" (Germany) was chosen for the calculation of reinforced concrete structures of tier buildings. The characteristics of fire protection compounds and their regulation, which are usually used, also are shown. According to the new code "Highrise buildings and complexes. Fire safety requirements", limits of fire resistance for walls of not less than 240 minutes. Skyscraper "Lakhta center" with a height of $462 \mathrm{~m}$ and limits of fire resistance of loadbearing reinforced concrete structures 180 and 240 minutes is built up in Russia. The article investigates the means of fire protection in the business center. Moreover, modern form of cladding in Mada Residences building (Dubai, UAE) is concerned to make some conclusions about future fire resistant solutions.
\end{abstract}

\section{Introduction}

High-rise buildings and multifunctional complexes are divided into fire compartments by their functional purpose, floor area, and the total height of the building. The boundaries of fire compartments are fire barriers: fire walls and floors with the normative limits of fire resistance. The required parameters of fire resistance of building structures are defined depending on its purpose, height, and value of the combustible load. So, in the abovementioned objects, the fire resistance rating varies from 3 to $4 \mathrm{~h} \mathrm{[1].}$

The construction of tall buildings requires a heightened fire safety. One of the most important tasks is to protect bearing structures from the effects of dangerous factors of a fire to prevent their premature collapse. In this regard, the theme of ways of improving the fire resistance of structures is relevant, for example, by using the plaster compositions on the supporting part of the building.

Building structures are characterized by fire resistance and fire hazard [2]. The fire resistance of the structure is a time for the construction to fulfill its design purpose in fire conditions [1].

\footnotetext{
* Corresponding author: eliza gumerova@mail.ru
} 
There are no unified criteria for the classification of buildings by number of storeys in Russia, therefore it is considered in this work that high-rise building -6 floors and above. The practice of multi-storey massive construction focused on the height of buildings which value is not more than $75 \mathrm{~m}$ [3]. These buildings have a great degree of potential fire danger and greatly hampered evacuation $[4,5]$.

To provide the required evacuation, modern software systems are used increasingly in order to calculate the factors, project evacuation routes in different fire cases according to normative documents. Scenery of the development of pores and pore risk calculation by normative methodical. Such programs also calculate blocking time of escape ways by dangerous fire factors using some mathematic simulations. These programs, mainly, are based on international development "Fire Dynamic Simulation" (USA, Finland), in which the models for computation of smoke spread time and heat transition value. These program complexes can be used for calculating the thermal gradient in various building areas in order to define the heat degree of building constructions.

The reliability of high-rise buildings is determined by the ability of supporting structures to resist the effects of high temperatures [6]. Nowadays the following limit values of fire resistance for buildings to $100 \mathrm{~m}-150 \mathrm{~min}$, from $100 \mathrm{~m}$ to $150 \mathrm{~m}-180 \mathrm{~min}$, for buildings higher than $150 \mathrm{~m}-240 \mathrm{~min}$ [7]. In Russian Federation the new document new code "Highrise buildings and complexes. Fire safety requirements" is drafted.

It is possible to apply the various program complexes solving the corresponding problems, for calculation of the fire resistance, using the finite-element method. For example, the American program complex "Ansys" can calculate a full-fledged model of the structure, based on fire resistance parameter, at any point of the building. Since this software package is considered to be one of the most expensive and difficult to use, for simpler tasks (such as calculating the fire resistance of individual load-bearing elements) it is more rational to use such a program as "Abaqus", "Cype", "Elcat", "Sofistik", etc. The calculation of a typical concrete slab in this software package is shown on Fig. 1.

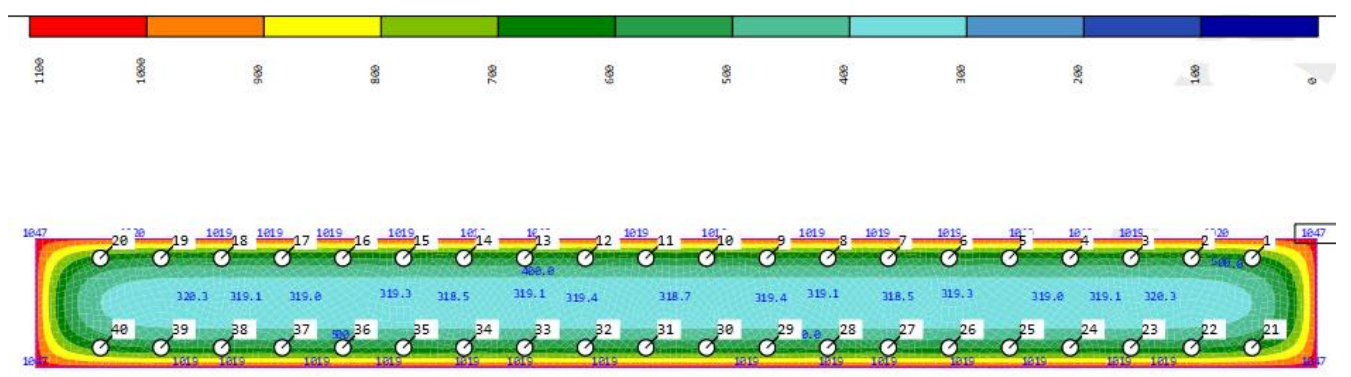

Fig. 1. Thermal gradient in calculation report in "Sofistik".

Since the software "Sofistik" uses a hypothesis Dupee for transition to the simplified task, it is necessary to set the geometric properties of structural section, materials and loads, acting on the element. Thickness is adopted $0.2 \mathrm{~m}$, width $2 \mathrm{~m}$ and compressive load $300 \mathrm{Kn}$ for the plate. According to the calculation, the fire resistance limit of the structural element is equal to R120.

According to the thermal gradient (Fig. 1), it is possible to determine the fire resistance limit of the reinforced concrete slab: the loss of bearing capacity will occur at the time of heating to 700 degrees of the reinforcement, which is under the thin protective concrete layer. On Fig. 2 there is an example of calculation of a reinforced concrete column without fire protection and with fire protection plaster composition "Fendolite" with its fire resistance limits to $180 \mathrm{~min}$. 


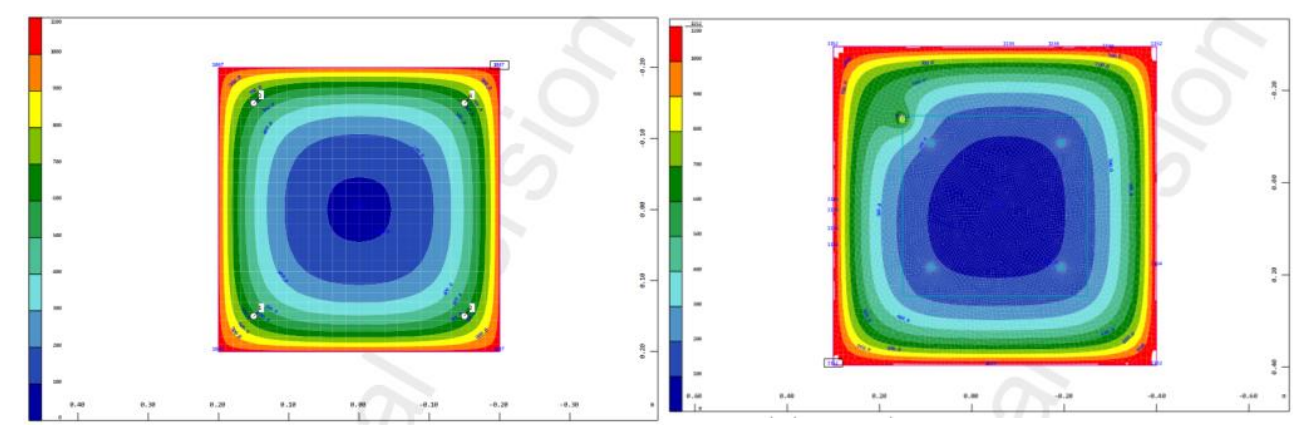

Fig. 2. Example of calculation of reinforced column $400 \times 400$ taking into account fire resistance on the left and on the right side.

Reinforced concrete high-rise buildings have considerable weight, which causes significant loads on the ground. Concrete constructions in the form of columns have high fire resistance, however, as the steel, they also prone to almost instant collapse in terms of limit loads $[9,10]$.

If the outer layers of the concrete are heated above $t>600$ degrees, the limit of their strength goes below the stress from the external load, and these layers in the column cease to participate in the perception of external loads. Therefore, only the central part of column section carries the load, i.e. it can be considered concrete, not reinforced.

The most basic ways in implementation are the methods for increasing the fire resistance of building constructions and elements of internal furnish by impregnating the protected surfaces with special flame retardants (impregnation, paints and varnishes) and protection by fire-resistant plasters $[3,11]$. It is especially important to be careful while using fire retardant coating in view of its special challenges and responsibilities [8].

Due to the normatives of Russian Federation $[2,7,19]$ there is no possibility to evaluate the value of time resistance of the object before the onset of progressive collapse. Skyscraper "Lakhta center" with a height of $462 \mathrm{~m}$ and limits of fire resistance of load-bearing reinforced concrete structures 180 and 240 minutes is built up in Russia.

\section{Fire resistance for structures in "Lakhta Center"}

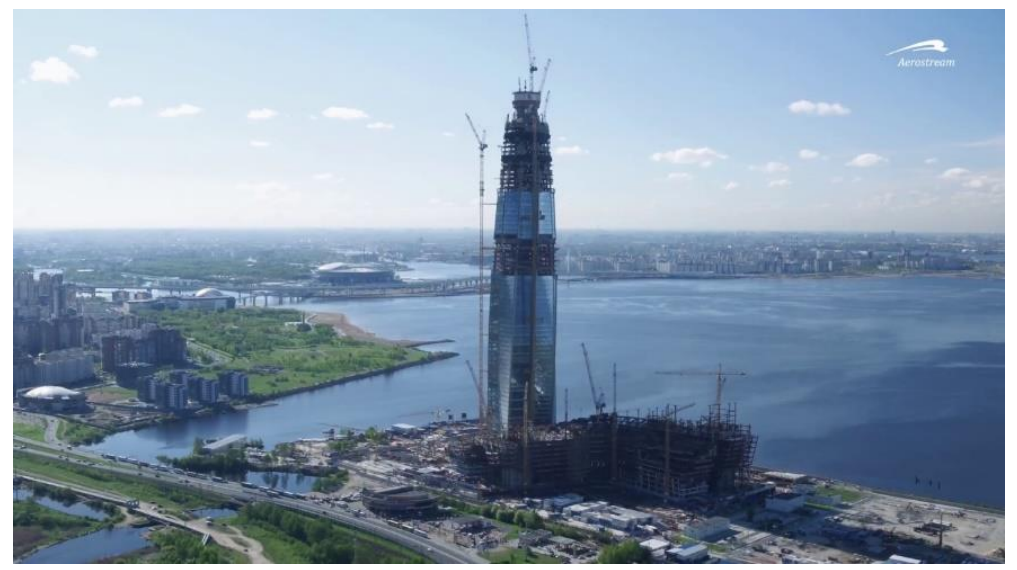

Fig. 3. Lakhta Center, Saint-Petersburg, Russia. 
Progressive fire extinguishing systems and traditional solutions are used fort fire safety in "Lakhta Center" (Fig. 3). The aim of fire protection system is to prevent case of fire, ensure the safety of people and protect the property. The evacuation of people from the floors of building Tower is provided by several variants:

- Safety corridors - corridor (station passage), the walling of which is made with the limits of fire resistance not less than 120 minutes, protected by system of smoke ventilation. Such corridors are aimed at the safe movement of people from the premises to the stair enclosures in case of fire,

- Two smokeproof stairways, equipped with air boosting device and entrance through pressurized lobby,

- Two emergency exits to the evacuation stairwell of the building. Evacuation is from the upper level of observation deck - on a curved ramp with a slope, or by internal open staircase to the lower level,

- All escape routes have such width that it could easily carry a stretcher.

\subsection{The degree of fire resistance}

The degree of fire resistance with increased limits up to R/REI 240, i.e. 240 minutes (4 hours) is foreseen for the building of Tower.

Reinforced concrete bearing elements of the parts of the building under and above the ground, the ceiling elements have protective layers of concrete until the adapter fitting not less than $45-70 \mathrm{~mm}$.

Steel bearing elements of the building frame and the secondary beam of ceilings are paved with fire-retardant materials (flame retardants, board materials).

Steel bearing elements of operated and decommissioned coatings, elements of stairwells and staircases have a fire-retardant treatment by intumescent paints or paved with fire resistant materials.

\subsection{Plastering}

We will consider the most effective and easy-to-use method of fireproofing - plastering [12]. There are many available technologies that can be used depending on the particular type of building. The main indicator of the plaster materials is the cohesion that means bond strength. A threshold value is $1000 \mathrm{psf}=47,88025 \mathrm{kPa}$ for buildings taller than 420 feet (128 m) [13]. Boundary value of the bond strength is $430 \mathrm{psf}=20,597 \mathrm{kPa}$ for buildings with height below $420 \mathrm{ft}(128 \mathrm{~m})$. According to American standards fire resistant means of similar bulk density (up to $240 \mathrm{~kg} / \mathrm{m}^{3}$ ) and the method of applying, for example, marks Monokote MK-6 GF, Monokote MK-6/HY, Monokote Z-106/G (manufacturer: Grace, USA) are not allowed for use in high-rise construction (above $128 \mathrm{~m}$ ) [14, 15].

Sand-cement plaster with thickness $25-60 \mathrm{~mm}$, which is applied on the steel mesh, is used to increase fire resistance limit of metal structures up to 2 hours or more. Plaster with the thickness of 40-60 $\mathrm{mm}$ is reinforced with double mesh, which protects it from premature collapse in case of fire.

The most important properties of the plasters can be easily changed by putting additives in mixture $[16,17]$. As tests show, samples of vermiculite solution with volumetric weight from 500 to $800 \mathrm{~kg} / \mathrm{m}^{3}$, which are heated to temperature of $900-1000{ }^{\circ} \mathrm{C}$ and placed in water, do not crack and retain sufficient strength, while samples of cellular concrete under the same conditions are completely destroyed. Fire-retardant efficiency of vermiculite solutions is in 4 times higher than of the sand. Thus, the limit of fire resistance of roofs and ceilings, which is equal to $1.5 \mathrm{~h}$, is provided at a thickness of a layer of vermiculite fireproofing solution of $8 \mathrm{~mm}$ (table 1). 
Expanded vermiculite is a loose, porous material in the form of scaly particles, which are produced by rapid firing of vermiculite concentrate - hydromica, which contains bound water between elementary layers. Steam, which is generated from this water, pushes the plates of mica and increases the initial volume of grains in the 6-15 times or more $[18,19]$. Unique technical features of it are temperature resistance, fire resistance, reflectivity, and chemical inertness. It does not emit any gases, which is an important advantage in comparison with other known materials of organic origin at increased temperatures.

Table 1. Fire resistance of building finishing materials.

\begin{tabular}{|c|c|c|c|}
\hline $\begin{array}{c}\text { Type of } \\
\text { insulation }\end{array}$ & $\begin{array}{c}\text { Density, } \\
{\left[\mathrm{kg} / \mathrm{m}^{3}\right]}\end{array}$ & Width, [mm] & $\begin{array}{c}\text { Fire } \\
\text { resistance } \\
\text { limit, [min] }\end{array}$ \\
\hline Cement slab & $250-300$ & 40 & 110 \\
\hline $\begin{array}{c}\text { Cement slab } \\
\text { with plaster }\end{array}$ & $250-300$ & 50 & 155 \\
\hline Loam brick & 1500 & 120 & 325 \\
\hline $\begin{array}{c}\text { Loam brick } \\
\text { with plaster }\end{array}$ & 1500 & 120 & 360 \\
\hline $\begin{array}{c}\text { Cement and } \\
\text { vermiculite } \\
\text { plaster }\end{array}$ & 500 & 15 & 600 \\
\hline
\end{tabular}

Table 2. Characteristics of compounds of fire-retandant vermiculite building solutions.

\begin{tabular}{|c|c|c|c|c|}
\hline \multirow{2}{*}{$\begin{array}{c}\text { Composition } \\
\text { (by volume) }\end{array}$} & \multirow{2}{*}{$\begin{array}{c}\text { Density, } \\
{\left[\mathrm{kg} / \mathrm{m}^{3}\right]}\end{array}$} & \multicolumn{2}{|c|}{ Strength, $\left[\mathrm{kg} / \mathrm{cm}^{2}\right]$} & \multirow{2}{*}{$\begin{array}{c}\text { Width of } \\
\text { layer, [mm] }\end{array}$} \\
\cline { 3 - 5 } & 500 & 12.5 & 8.2 & 13.5 \\
\hline $\begin{array}{c}\text { Cement and } \\
\text { vermiculite } \\
(1: 4)\end{array}$ & 450 & 16.8 & 11.5 & 31.2 \\
\hline $\begin{array}{c}\text { Cement and } \\
\text { vermiculite } \\
(1: 6)\end{array}$ & 300 & 10.8 & 7.8 & 13.4 \\
\hline $\begin{array}{c}\text { Cement and } \\
\text { vermiculite } \\
(1: 7)\end{array}$ & 350 & 2.5 & - & 20 \\
\hline $\begin{array}{c}\text { Gypsum- } \\
\text { vermiculite } \\
(1: 3)\end{array}$ & & & Bend & \\
\hline
\end{tabular}

Portland cement with grade, which is not lower than M-400, plaster with grade not lower than G5 and vermiculite $0.6-2 \mathrm{~mm}$ are used for the preparation of these compounds.

The plaster mix which on the basis of exfoliated vermiculite and calcium aluminate cement (M-400) with the addition of asbestos has the most effective flame retardant properties. 
Such plaster coating is related to group of heat-resistant and can withstand temperatures over $800{ }^{\circ} \mathrm{C}$ (table 3$)$.

Table 3. Fire resistance of building finishing materials.

\begin{tabular}{|c|c|c|}
\hline $\begin{array}{c}\text { Composit } \\
\text { Cemt/vermiculite/ } \\
\text { asbestos }\end{array}$ & Density, $\left[\mathrm{kg} / \mathrm{m}^{3}\right]$ & Width of layer, $[\mathrm{mm}]$ \\
\hline $1 / 2 /(3-4 \%$ from weight of cement $)$ & $800-900$ & $10-13$ \\
\hline $1 / 1 /(15 \%$ from weight of cement $)$ & $1100-1200$ & $12-15$ \\
\hline
\end{tabular}

Plasters on cement can be applied indoors and outside. The compositions and paint compositions on liquid glass and the plaster are only for interior use in areas with humidity no more than $85 \%$. The most popular plasters for improving the fire resistance of bearing structures are in table 4,5 .

Table 4. Comparative properties of plaster compositions [15].

\begin{tabular}{|c|c|c|c|c|c|}
\hline & Composition & $\begin{array}{l}\text { Fire resistance } \\
\text { limit }\end{array}$ & Durability, years & Density $\left[\mathrm{kg} / \mathrm{m}^{3}\right]$ & $\begin{array}{c}\text { Required } \\
\text { thickness of } \\
\text { layer } \\
\text { [mm] }\end{array}$ \\
\hline $\begin{array}{c}\text { Cafco Fendolite } \\
\circledR\end{array}$ & $\begin{array}{l}\text { Vermiculite and } \\
\text { portlandcement }\end{array}$ & REI240 & 50 & - & 10 \\
\hline Neospray & $\begin{array}{c}\text { Vermiculite and } \\
\text { portlandcement } \\
\text { and additives }\end{array}$ & REI240 & 25 & 490 & 22 \\
\hline Sosh-1 & $\begin{array}{c}\text { Perlite and } \\
\text { organic additives }\end{array}$ & REI180 & 20 & 450 & 30 \\
\hline Krilak & $\begin{array}{l}\text { Binding with } \\
\text { additives }\end{array}$ & REI240 & 50 & $690-850$ & 18 \\
\hline Vimark & Gypsum & REI 120 & - & 750 & 15 \\
\hline ByProc & Cement & REI240 & 40 & 750 & 15 \\
\hline Fassa KF 4 & Perlite & REI180 & 50 & $700-820$ & 10 \\
\hline $\begin{array}{c}\text { Knauf Italia } \\
\text { FP120 }\end{array}$ & Portlandcement & REI200 & - & 650 & 20 \\
\hline
\end{tabular}


Table 5. Fire resistance of building finishing materials.

\begin{tabular}{|c|c|c|c|c|c|c|c|}
\hline Product & $\begin{array}{l}\text { Density } \\
{\left[\mathrm{kg} / \mathrm{m}^{3}\right]}\end{array}$ & $\begin{array}{l}<75 \\
\text { feet }\end{array}$ & $\begin{array}{c}>75 \text { feet } \\
<420 \\
\text { feet }\end{array}$ & $\begin{array}{l}>420 \\
\text { feet }\end{array}$ & $\begin{array}{l}\text { Garage } \\
\text { Parking }\end{array}$ & Pools & $\begin{array}{l}\text { External } \\
\text { impression }\end{array}$ \\
\hline $\begin{array}{c}\text { Monokote } \\
\text { MK-6/HY, } \\
\text { MK-6 GF (a) }\end{array}$ & 15 & - & & & & & \\
\hline $\begin{array}{c}\text { Monokote MK- } \\
10 / \mathrm{HB}\end{array}$ & 15 & - & - & & & & \\
\hline $\begin{array}{c}\text { Monokote MK- } \\
1000 / \mathrm{HB}\end{array}$ & 18 & - & - & - & & & \\
\hline $\begin{array}{c}\text { Monokote Z- } \\
106 / \mathrm{G}\end{array}$ & 22 & - & - & & & & \\
\hline $\begin{array}{c}\text { Monokote Z- } \\
106 / \mathrm{HY}\end{array}$ & 22 & - & - & - & - & - & \\
\hline Monokote Z-146 & 40 & - & - & - & - & - & - \\
\hline Monokote Z-156 & 50 & - & - & - & - & - & - \\
\hline
\end{tabular}

\section{Modern plaster composition in UAE}

Developed in Spain and made from extruded porcelain, it has been specified by Artar Real Estate Development for the 36-storey Mada Residences building, which will be completed in the second quarter in 2018 rapidly taking shape at the heart of Dubai's Downtown district (Fig. 4).

Artar Real Estate also said that Mada Residences is "the first residential tower in Dubai built using specially developed cladding that can resist temperatures of up to $1200{ }^{\circ} \mathrm{C}$ ".

The company said it decided to the use the new cladding after inspecting its fire resistant qualities at the manufacturing facility in Spain. The insulation powers of the new cladding panels also reduce $\mathrm{AC}$ consumption in the summer to produce energy savings of up to 30 per cent, it added.

The project's scope of work consist of a 39-storey residential tower offers intelligently designed and spacious luxury 2, 3 and 4-bed apartments located in Downtown Dubai, Dubai. The project includes spacious layouts ranging from 2,852 square feet to 3,234 square feet, the luxury residences come with Bianco Venus marble floors, generous European designed kitchens and some of the largest terraces.

Each apartment has been crafted with family-centric livability for those who love their spacious spaces. With floor to ceiling glass, balconies in every apartment and well thoughtout amenities designed in a way that elevates the usability of space and achieves enduring value.

The intelligent use of space becomes evident from the moment you enter the reception, all the way to the apartments, where every bedroom comes with an en-suite bathroom. Spacious walk-in closets and balconies are core features and benefits resulting from adhering to the concept of livability. 


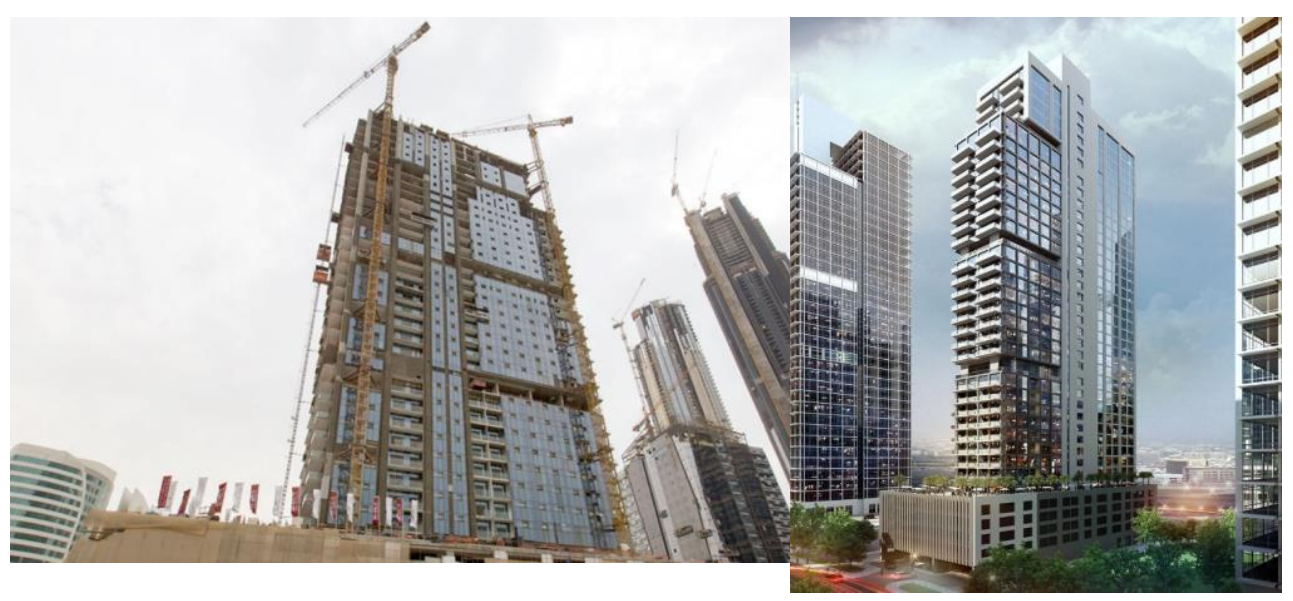

Fig. 4. a) Construction, July 2017 b) Project of Mada Residences

Progressive fire extinguishing systems and traditional solutions are used fort fire safety in "Lakhta Center". The aim of fire protection system is to prevent case of fire, ensure the safety of people and protect the property. The evacuation of people from the floors of building Tower is provided by several variants:

- Safety corridors - corridor (station passage), the walling of which is made with the limits of fire resistance not less than 120 minutes, protected by system of smoke ventilation. Such corridors are aimed at the safe movement of people from the premises to the stair enclosures in case of fire,

- Two smokeproof stairways, equipped with air boosting device and entrance through pressurized lobby,

- Two emergency exits to the evacuation stairwell of the building. Evacuation is from the upper level of observation deck - on a curved ramp with a slope, or by internal open staircase to the lower level,

- All escape routes have such width that it could easily carry a stretcher.

\section{Prospects for the development of fire-resistant plaster compositions}

- The creation of materials with low density that form a light coating and do not have a significant additional load on the bearing structures,

- Development of methods for the determination of coating thickness depending on the thickness of the metal and the required fire resistance of steel structures, which will allow to calculate quickly and accurately the development of the project of fire protection of structures,

- Increase of the adhesion and cohesion of the plaster. In compliance with the regulatory requirements the material shall not crack and does not flake off. The formation of the coating without joints and thermal bridges.

It is need to consider the probability of occurrence of emergency situations, during which the building will be experienced the multiple loads. Hence there is necessity of using some special regulations. In contrast to the normative documents of the Russian Federation, a part of which is the translation of relevant foreign, there is a positive experience of application of regulations in international practice. 
In the standards, these regulations are embodied in the form of special features of fire resistance of structures and buildings as the ability of these facilities for a certain period of time to resist the combined special effects of working loads on the structure and hightemperature fire. Rules, which describe the bond strength in the USA, have been taken primarily as anti-terrorist. Light plaster will be blown or damaged in case of intensive fire exposure convection and the shock wave.

In this regard, fire resistant plasters should possess improved adhesion and cohesion.

In the rules of there is a note that special technical conditions should be developed for specific buildings and reflect the specifics of their fire protection, including additional technical and organizational measures. Specific technical specifications must be supported by necessary calculations.

Fire resistance limits of load-bearing structures should be at least 4 hours and building structures must resist to temperature of $1100^{\circ} \mathrm{C}$ for buildings with height more than $100 \mathrm{~m}$. Consequently, it is necessary to tighten all of the requirements for the fire resistance of the buildings.

The methods which are established by the standard should be applied while establishing the fire resistance limits of structures to determine their applicability. Due to the international experience, the fire resistance limits of building structures above: R120 for load-bearing elements of the building; REI60 for ceilings between the floors and over basements; REI120 for stairwells, should be provided in high-rise buildings.

\section{References}

1. Federal Law of the Russian Federation FL-123. Technical Regulations on fire safety requirements (2008)

2. MA Qian-li, Huang Ting-lin,. Procedia Engineering, 11 (2011)

3. O. Halyavin, M. Gravit, A. Pryanikova. Saint Petersburg State Polytechnic University Science Week (2015)

4. P. Kolarkar, M. Mahendran. Fire Saf. J. 53, 85-104 (2012)

5. A. Ulybin, N. Vatin. Journal of the unique construction of buildings and structures. $\mathbf{1 0}$ (25) (2014)

6. B. Schafer. Steel Constr. 4(3) (2011)

7. Project of Russian normative document. Highrise buildings and complexes. Fire safety requirements.

8. Roger G. Morse. Fireproofing at the WTC towers. Fire Engineering 10/01/2002

9. V. Roitman. Rationing protect tall buildings from the progressive destruction at the combined special therapeutic effects. Fire and explosion safety part. 16 (2) (2007)

10. V. M. Roitman. Construction Security, 871 (2006)

11. V. Roitman. Global Security, 871 (2006)

12. G. Craighead. High-Rise Security and Fire Life Safety (2009)

13. J. Lataille. Fire Protection Engineering in Building Design (2002)

14. L. Huanga, T. Chen, H. Yuan, Transportation Research Procedia, 2, 518-523 (2014)

15. International Building Code, Section 403, High-rise Building (2009)

16. M. Gravit, E. Mikhailov, S. Svintsov, A. Kolobzarov, I. Popovych. Materials Science Forum, 871 (2016)

17. P.Stephenson, Institution of Fire Engineers in the Middle East [online] Available at: https://gulffire.mdmpublishing.com/fire-engineering-in-the-middle-east/ (2018) 
18. Construction updates - Mada residences [online], Available at: http://www.madaresidences.ae/construction-updates.html (2017)

19. Construction updates of Dubai's Mada Residences revealed [online], Available at: http://www.constructionweekonline.com/article-46829-construction-updates-of-dubaismada-residences-revealed/ (2017)

20. Lakhta-center. [online], Available at: http://lakhta.center/ru/ (2018) 